\title{
European Association for the Study of Diabetes: 1965-1984
}

\author{
J.G. L. Jackson
}

European Association for the Study of Diabetes, London, UK

The formation of the European Association for the Study of Diabetes (EASD) was preceded by many personal discussions between individuals in Europe who were in favour of the simultaneous creation both of an Association and of a new, European, journal of diabetes-related clinical and biological research. To start a new association without the means of expression through a journal was thought to be of little practical value; and to start a journal without the backing of an authoritative and responsible organisation might well jeopardise the maintenance of desirable standards of scientific quality. Thus the two projects were indisputedly linked and have remained so.

In July 1964, during the Fifth Congress of the International Diabetes Federation (IDF) in Toronto, Canada, some 70 European doctors and scientists met to continue their informal discussions under the Chairmanship of the late Professor Dr. J.P. Hoet (Belgium), and unanimously agreed to the formation of the Association. A Steering Committee of 16 members was appointed, and Professor A.E. Renold (Switzerland) accepted the heavy responsibility of the interim secretaryship in order to expedite matters, which included arrangements for the first Annual Meeting planned for Spring, 1965. At the same time, Professor Dr. K. Oberdisse (FRG) was asked to continue his negotiations with various publishing houses with a view to the publication of a journal under the title Diabetologia which would be in the same size and format as Diabetes, the journal of the American Diabetes Association, so that the two could be bound together.

Over the next 6 months there was considerable activity. A constitution was drafted in accordance with Swiss law, the headquarters of the Association being established in Geneva. Approaches were made to industry for financial support, and Springer-Verlag was selected as publisher. Professor Renold travelled to Montecatini, Italy, to meet with Professor S. Signorelli and colleagues to make arrangements for the first meeting.

Initially it was suggested that the Association might meet annually in the same place, but our arrival in Mon- tecatini in April 1965 coincided with the coldest spring in Italy for 30 years and a rapid decision was taken to adopt trans-european travel! The decision on venues of Annual Meetings is taken by the Council, based on invitations received from national diabetes organisations or from groups of individuals, although on occasion initiative has been taken to extract an invitation from less willing colleagues. As a rule, the venue is decided 3 years in advance but in 1974, when the Association was due to meet in Athens, the imprisonment and torture of a Greek member led the Executive Committee to cancel the arrangements. Both Yugoslavia and Israel were willing to take over the meeting at short notice, but the only available dates for the former coincided with the start of the academic year, so the decision was taken to accept the invitation to travel to Jerusalem.

Initially, university facilities were the favoured venue, but as the popularity of the meetings grew, so the availability of suitable premises within university complexes diminished. Few universities have sufficiently large lecture theatres to cater for plenary sessions which may attract up to 1000 people (in recent years, up to 2000), and there has been a growing tendency to hold meetings in hotel complexes, or in purpose-built congress centres which, whilst ideal in terms of facilities, are expensive to hire and may lack the environmental atmosphere which can contribute to the interchange of ideas. Such is the increase in the number of meetings in a multitude of different disciplines and topics that it is now essential to plan up to 6 years in advance if the most suitable premises are to be obtained, and the essential accommodation reserved.

\section{Constitution and officers}

The Constitution of the Association was adopted at the first General Assembly held in Montecatini, Italy, on Wednesday 21 April 1965, which was attended by 233 individuals. From the Council of 15 members, Professor F. G. Young (Cambridge) was elected President, Professor A.E. Renold (Geneva), Honorary Secretary, and 
Table 1. Officers 1964-1984

\begin{tabular}{|c|c|}
\hline Presidents & Vice-presidents \\
\hline \multirow[t]{2}{*}{1964 Hoet JP+(Belgium) } & 1965 Lundbaek K (Denmark) \\
\hline & 1965 Martin $\mathrm{E} \dagger$ (Switzerland) \\
\hline \multirow[t]{2}{*}{1965 Young FG(UK) } & 1968 Czyzyk A (Poland) \\
\hline & 1969 Butterfield WJH (UK) \\
\hline \multirow[t]{2}{*}{1968 Lundbaek K (Denmark) } & 1969 Derot M (France) \\
\hline & 1971 Hellman B (Sweden) \\
\hline \multirow[t]{2}{*}{1971 Creutzfeldt W (FRG) } & 1972 Vague J (France) \\
\hline & 1973 Nikkila EA (Finland) \\
\hline \multirow[t]{2}{*}{1974 Renoid AE (Switzerland) } & 1975 Mirouze J (France) \\
\hline & 1976 Sailer S (Austria) \\
\hline \multirow[t]{2}{*}{1977 Randle PJ (UK) } & 1978 Lenti G (Italy) \\
\hline & 1979 Bouman PR (The Nether- \\
\hline \multirow[t]{2}{*}{1980 Gepts W (Belgium) } & lands) \\
\hline & 1980 Binder C (Denmark) \\
\hline \multirow[t]{2}{*}{1983 Andreani D (Italy) } & 1981 Freychet P (France) \\
\hline & 1982 Waldhäusl WK(Austria) \\
\hline Honorary secretaries & Honorary treasurers \\
\hline 1965 Renold AE (Switzerland) & 1965 Pfeiffer EF (FRG) \\
\hline 1970 Conard $V \dagger($ Belgium $)$ & 1969 Schöffling K (FRG) \\
\hline 1973 Hellman B (Sweden) & 1972 Mahler RF (UK) \\
\hline 1976 Lefebvre PJ (Belgium) & 1975 Hockaday TDR (UK) \\
\hline 1979 Hepp KD (FRG) & 1978 Canivet $\mathrm{J}$ (France) \\
\hline \multirow[t]{2}{*}{1982 Alberti KGMM (UK) } & 1981 Andreani D (Italy) \\
\hline & $\begin{array}{l}1982 \text { Krans HMJ (The Nether- } \\
\text { lands) }\end{array}$ \\
\hline
\end{tabular}

Professor Dr. E. F. Pfeiffer (Frankfurt), Honorary Treasurer. A system of rotation was instituted by ballot to allow for a maximum term of office of 3 years, although initially the Treasurer and Secretary served for 4 and 5 years respectively to provide the essential continuity in the early stages. In addition, Professor Dr. J.P. Hoet (Louvain) was elected as Immediate Past President, and Professor Dr. K. Oberdisse (Düsseldorf) as Editor-inChief of Diabetologia, both being members ex-officio of the Council.

In 1970 the Constitution was amended to allow the election of the Secretary and Treasurer from amongst the active membership, who thus become members 'exofficio' of the Council; and in 1979 a further amendment endorsed the appointment of the Chairman and Secretary of the Postgraduate Education sub-committee as additional 'ex-officio' members of the Council.

The President, Vice-Presidents, Honorary Treasurer and Honorary Secretary, Editor-in-Chief of Diabetologia and Chairman of the Postgraduate Education subcommittee form the Executive Committee, which since 1970 has met annually to consider matters of administration and to make recommendations to the Council, which meets twice annually at the time of the Annual Meetings.

Those who have been elected to the Offices of the Association are shown in Table 1. Those who have served on the Council, by country, over the first 20 years are given in Table 2.

To avoid the administrative problems of having a central office which moved every 3 years with the incoming Honorary Secretary, the opportunity was taken, on the retirement of Dr. Renold from that office, to es-
Table 2. Composition of Council 1965-1984

\begin{tabular}{|c|c|}
\hline Austria & H Maske, A Beringer, S Sailer, WKWaldhäusl \\
\hline Belgium & $\begin{array}{l}\text { JP Hoet, AP Bastenie, VConard, PJ Lefebvre, } \\
\text { J Pirart, JJ Hoet, WJ Malaisse, WGepts, A Luyckx }\end{array}$ \\
\hline Bulgaria & DAndreey \\
\hline Czechoslovakia & RKorec \\
\hline Denmark & $\begin{array}{l}\text { M Jersild, K Lundback, JE Poulsen, J Schlichtkrull, } \\
\text { T Deckert, C Binder, LGHeding }\end{array}$ \\
\hline Finland & EA Nikkila, VA Koivisto \\
\hline France & $\begin{array}{l}\text { M Derot, A Loubatieres, J Vague, RAssan, J Mi- } \\
\text { rouze, J Canivet, GTchobroutsky, PFreychet }\end{array}$ \\
\hline GDR & VSchliack, K Seige, H Bibergeil \\
\hline FRG & $\begin{array}{l}\text { H Bartelheimer, EF Pfeiffer, W Creutzfeldt, } \\
\text { H-D Söling, K Schöffling, KD Hepp, H Frerichs, } \\
\text { KF Weinges, HH Schöne, E Standl }\end{array}$ \\
\hline Greece & JGAlivisatos, D Ikkos, A Rigas, S Raptis \\
\hline Hungary & I Magyar, GTamas \\
\hline Israel & EShafrir, ECerasi \\
\hline Italy & $\begin{array}{l}\text { SSignorelli, M Coppo, G Pozza, D Andreani, } \\
\text { LAdezati, G Lenti, GCrepaldi }\end{array}$ \\
\hline Netherlands & $\begin{array}{l}\text { AWM Pompen, FM Gerritzen, PR Bouman, } \\
\text { HMJ Krans }\end{array}$ \\
\hline Norway & J Jervell \\
\hline Poland & ACzyzyk, JTaton \\
\hline Portugal & PE Lisboa \\
\hline Romania & I Pavel, I Mincu \\
\hline Spain & $\begin{array}{l}\text { JL Rodriguez-Minon, JR Candela, M Serrano-Rios, } \\
\text { J Tamarit, I Valverde }\end{array}$ \\
\hline Sweden & $\begin{array}{l}\text { R Luft, B Hellman, C Hellerström, I-B Taljedal, } \\
\text { J Wahren }\end{array}$ \\
\hline Switzerland & $\begin{array}{l}\text { E Martin, AE Renold, ER Froesch, WStauffacher, } \\
\text { A Labhart, B Jeanrenaud, J-P Assal }\end{array}$ \\
\hline UK & $\begin{array}{l}\text { EB Chain, FG Young, TR Fraser, WJH Butterfield, } \\
\text { PJ Randle, DA Pyke, H Keen, RF Mahler, } \\
\text { TDR Hockaday, CN Hales, KD Buchanan, } \\
\text { PH Sonksen, KGMM Alberti, RB Tattersall }\end{array}$ \\
\hline Yugoslavia & ZSkrabalo, G Katona \\
\hline
\end{tabular}

tablish a permanent Secretariat under a paid Executive Director. Mr. J. G. L. Jackson, then Secretary-General of the British Diabetic Association, was appointed to this position and the Secretariat therefore moved to London in 1970.

\section{Membership}

The Association is firmly based on individual commitment. Initially, the membership embraced all those whose names were provided by national medical and scientific organisations in Europe but the advent of a permanent Secretariat in 1970 , and the need to pay for it, lead to a rapid decline and the eventual removal from our records of those who did not pay an annual subscription. However, it must be emphasized that the 

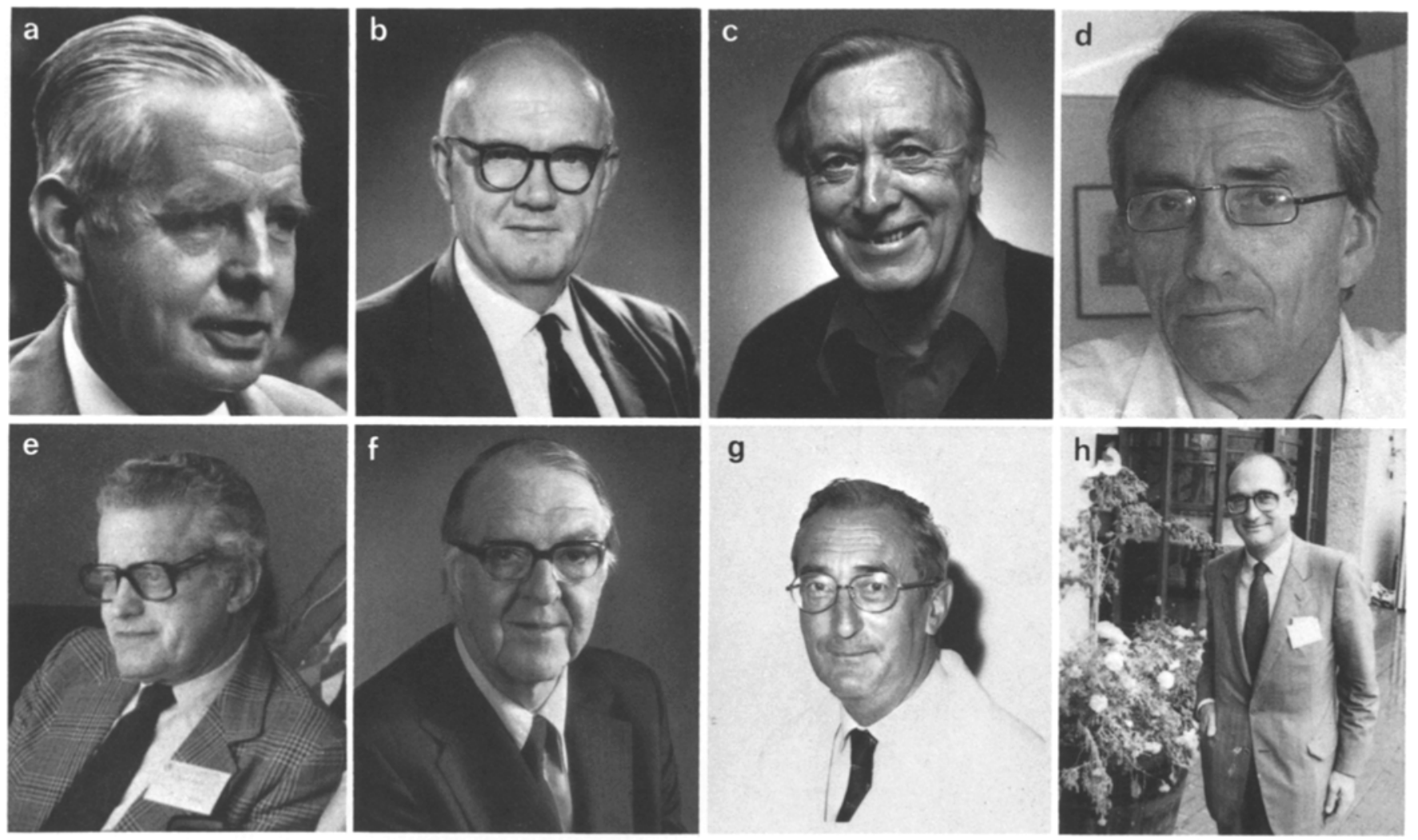

Fig.1 a-b. Presidents of the EASD. a J.P. Hoet, 1964. b Sir Frank Young, 1965-1968. c K. Lundbaek, 1968-1971. d W. Creutzfeldt, $1971-1974$. e A. E. Renold, 1974-1977. f P.J. Randle, 1977-1980. g W. Gepts, 1980-1983. h D. Andreani, 1983 -

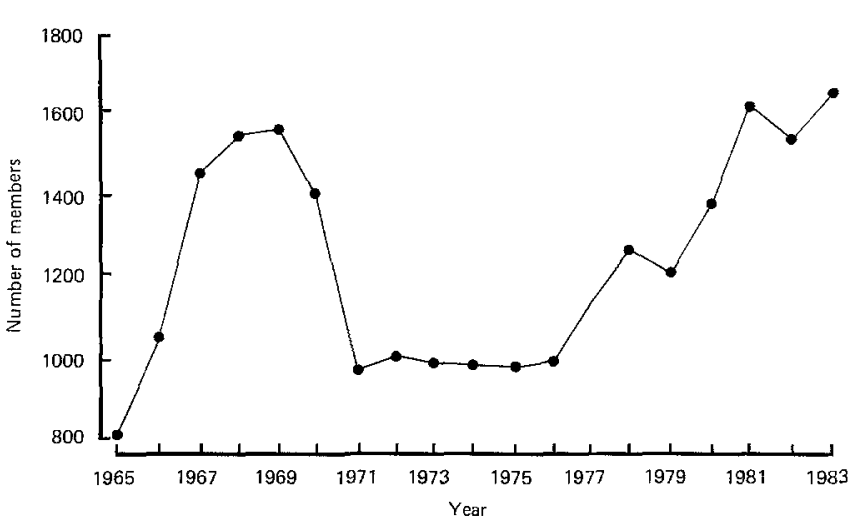

Fig. 1. Membership of EASD: $1965-1983$

names of members in Eastern European countries are never removed except in the case of death, or on the return of correspondence marked "gone away".

The rise, fall and subsequent rise of the total membership are shown in Figure 1. The occasional falls generally coincide with those years in which there is no annual scientific meeting, or an increase in the annual subscription rates. The rises are significantly linked with the venues of our Annual Meetings, coupled with the fact that a $50 \%$ reduction in the registration fee (introduced in 1974) is a powerful incentive to join.

The membership within individual countries over the last 10 years is shown in Figure 2. But this is not to deny the important contribution of many smaller nations, and indeed our membership now extends to more than 50 countries, including Japan, Australia and New Zealand to the east, and Argentina, Brazil and Chile to the west. Of the three categories of membership, only Active Members are eligible for election to the Council. Associate membership covers those interested in diabetes who are not medically or scientifically qualified. Supporting Members are companies which give "substantial material aid" to the aims of EASD.

The Constitution requires that all categories of membership pay an annual membership fee. Keeping track of such payments has often required the combined deductive skills of M. Maigret, Hercule Poirot and Sherlock Holmes!

Bestowal of Honorary Membership is the highest honour which the General Assembly can award. Table 3 lists those whom the Association has so honoured.

\section{Named lectures}

At the first General Assembly, Professor Renold was able to announce the creation of the Minkowski Prize, generously sponsored by Hoechst AG. A sub-committee consisting of Drs. F.G. Young, R. Luft, H. Maske and A.E. Renold was appointed to draw up the regulations governing this award, which is limited to persons 


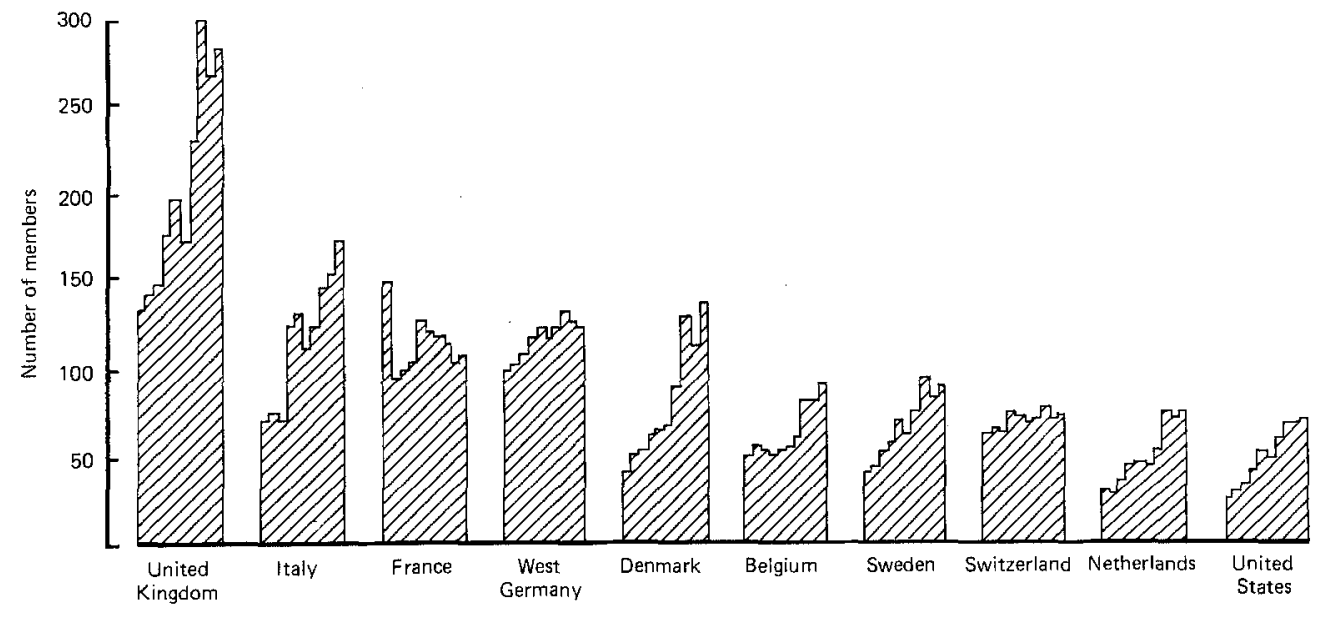

Fig. 2. Membership of EASD by country: 1974-1983
Table 3. Honorary members of EASD

CH Best $\div$ (Toronto, Canada)

Sir Henry Dale $\dagger$ (London, UK)

$M$ Derot (Paris, France)

HC Hagedorn $\uparrow$ (Copenhagen, Denmark)

BA Houssay $\uparrow$ (Buenos Aires, Argentina)

RD Lawrence $\dagger$ (London, UK)

R Levine (Duarte, USA)

RLuft (Stockholm, Sweden)

K Lundbaek (Aarhus, Denmark)

A Marble (Boston, USA)

KOberdisse (Düsseldorf, FRG)

Evon Wasielewski (Frankfurt, FRG)

Sir Frank Young (Cambridge, UK) normally resident in Europe who are under the age of 40 years on 1 January in the year in which the award is given, and is awarded for distinction manifested by publications which contribute to the advancement of knowledge concerning diabetes mellitus. The awards are decided by a sub-committee consisting of the President and Honorary Secretary ex-officio, two appointed members of EASD who serve for a maximum period of 3 years, and a representative of Hoechst AG.

The recipient receives a Triptych, a bronze half-relief of Oskar Minkowski, an honorarium of DM 10000, and travelling expenses to attend the Annual Meeting to deliver the Minkowski Lecture. The recipients, and the

Table 4. Minkowski lecturers: 1966-1984

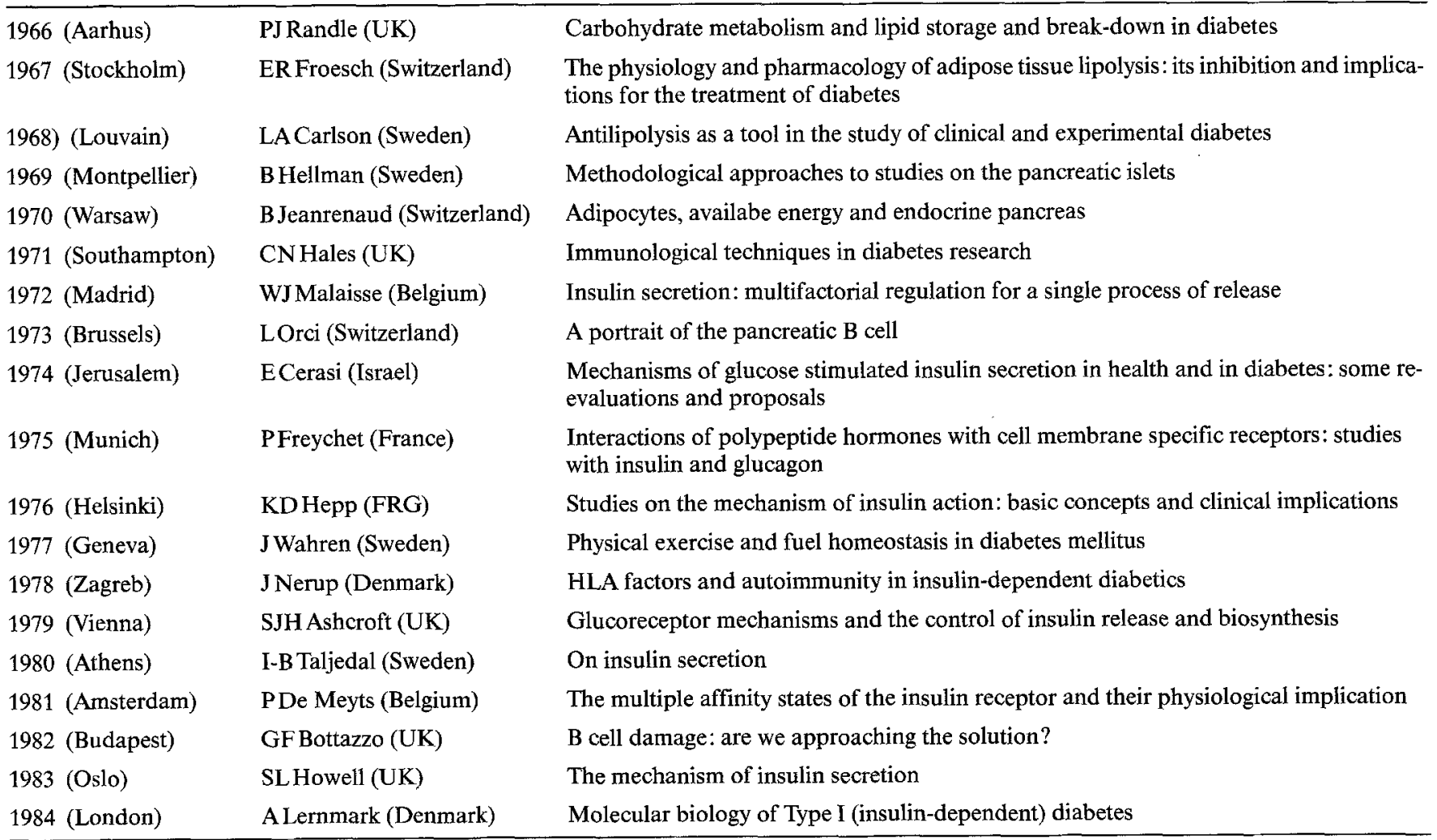


Tables 5. Claude Bernard Lecturers: 1969-1984

\begin{tabular}{|c|c|c|}
\hline 1969 (Montpellier) & C de Duve (Belgium) & Lysosomes, cellular pathology and diabetes \\
\hline 1970 (Warsaw) & EW Sutherland (USA) & The regulatory role of cyclic AMP \\
\hline 1971 (Southampton) & MDerot (France) & Progres dans l'investigation et le traitement des acidocetoses diabetiques severes \\
\hline 1973 (Brussels) & AE Renold (Switzerland) & $\begin{array}{l}\text { Experimental and spontaneous diabetic syndromes in animals (a re-evaluation of } \\
\text { their usefulness for approaching the physio-pathology of diabetes in man) }\end{array}$ \\
\hline 1976 (Helsinki) & HG Hers (Belgium) & The homeostatic and hormonal control of the level of glycaemia by the liver \\
\hline 1977 (Geneva) & DLColeman (USA) & Diabetes syndromes in mice \\
\hline 1978 (Zagreb) & WCreutzfeldt (FRG) & The incretin concept today (with special reference to GIP) \\
\hline 1979 (Vienna) & DA Pyke (UK) & Diabetes; the genetic connections \\
\hline 1983 (Oslo) & C Hellerstrom (Sweden) & The life story of a B cell \\
\hline 1984 (London) & PJ Lefebvre (Belgium) & From plant physiology to human metabolic investigations \\
\hline
\end{tabular}

Table 6. Venues of Annual Meetings: 1965-1984

\begin{tabular}{lll}
\hline 1965 20-22 April & Montecatini, Italy \\
1966 6-8 August & Aarhus, Denmark \\
1967 31 July-4 August & (sixth IDF Congress) Stockholm, Sweden \\
1968 22-24 July & Louvain, Belgium \\
1969 16-18 September & Montpellier, France \\
1970 23-25 September & Warsaw, Poland \\
1971 15-17 September & Southampton, UK \\
1972 6-8 September & Madrid, Spain \\
1973 15-20 July & (Eight IDF Congress) Brussels, Belgium \\
1974 11-13 September & Jerusalem, Israel \\
1975 4-6 September & Munich, FRG \\
1976 1-3 September & Helsinki, Finland \\
1977 28-30 September & Geneva, Switzerland \\
$1978 ~ 28-30$ September & Zagreb, Yugoslavia \\
1979 9-14 September & (Tenth IDF Congress) Vienna, Austria \\
1980 24-27 September & Athens, Greece \\
1981 15-18 September & Amsterdam, The Netherlands \\
1982 1-4 September & Budapest, Hungary \\
1983 14-17 September & Oslo, Norway \\
1984 12-15 September & London, UK \\
\hline
\end{tabular}

titles of their lectures are given in Table 4. Twenty-two members from eight countries have served on the award sub-committee.

In 1969, through the inspiration of Professor J.P. Hoet and the instigation of Professor A. Loubatieres, a Claude Bernard Lecture was instituted, sponsored by the Association de Recherches Scientifiques Paul Neumann, Paris. The Lecturer is appointed by the Council, and receives the Claude Bernard Medal, an honorarium of FFr. 6000, and travelling expenses. Table 5 lists those whom the Association has honoured, and the titles of their lectures.

With the exception of those years in which the IDF Congress is held in Europe, EASD has met annually (Table 6). In IDF years, the General Assembly and the two named Lectures are incorporated into the Congress programme. Anyone who has attended all the 20 General Assemblies (unfortunately our records cannot identify anyone who has done so, since the records of participation are not available for all meetings) must have travelled at least 17843 miles $(28550 \mathrm{~km})$, will have visited most of the principal cities in Europe, and will have enjoyed superlative hospitality arranged by the local organizers.

\section{Diabetologia}

The new journal, Diabetologia, was launched as the official organ of the Association in August 1965 as a quarterly journal. To help get it started, the Association undertook to meet $50 \%$ of the publishing costs for the first 5 years. Subscription to the journal was not made mandatory for members, but a preferential discount was negotiated on their behalf; this has now risen to $50 \%$.

Articles were published in any one of three languages (English, French or German), with summaries in the all three. The journal appeared bi-monthly from 1967-1978. In 1973, following the Council's decision to adopt English as the language of the Association, the journal became anglicized and, since 1978, has been published monthly.

Sadly, the link with the Association membership has not materialized as was hoped, and only about $30 \%$ of the membership subscribe. Nevertheless, the size of the journal has constantly increased and the standard of publication has remained extremely high.

The names of those who have assumed the onerous responsibility of Editor-in-Chief, which is a 4-year term of office, are given in Table 7. 


\section{Annual meetings}

The programmes of the Annual Meetings are based on submitted abstracts, the number of which has increased dramatically (Fig.3). Selection of the programme is made by a Programme Committee appointed each year, of which the Honorary Secretary is the Chairman and Convenor. Forty-three members from 17 countries have served on the Programme Committee, which invariably includes a representative of the local Organizing Committee.

From an initial acceptance rate of $37 \%$ in 1965 , there has been a steady increase to around $64 \%$. The considerably higher acceptance rate for 1974, when we met in Jerusalem, was in part due to the inclusion for the first time of poster sessions. Since that time, there have been other innovations - Poster Discussion Sessions (introduced in Zagreb, 1978), State of the Art Lectures (Amsterdam, 1981), and a Workshop (Oslo, 1983).

In order to do this, we have progressed from an original 1 1/2-day meeting of plenary sessions only, through $2^{1 / 2}$ day to $3^{1 / 2}$-day meetings since 1980 , coupled with a

Table 7. Editors-in-chief of Diabetologia: 1965-1984

\begin{tabular}{|c|c|c|}
\hline 1965 & K. Oberdisse & FRG \\
\hline 1973 & $\left.\begin{array}{l}\text { W. Creutzfeldt } \\
\text { K.Schöffling }\end{array}\right\}$ & FRG \\
\hline 1977 & K.G.M.M. Alberti & UK \\
\hline 1981 & A. G.Cudworth $\dagger$ & UK \\
\hline 1983 & M. Berger & FRG \\
\hline
\end{tabular}

constantly increasing number of parallel sessions but always, with one exception, retaining 2 half-days of plenary sessions. In addition to the two named lectures, it is usual for a local "Named Lecture" to be included in the programme.

\section{Abstracts}

Initially, all abstracts received were published in a separate volume, reproduced photographically and published in at least one additional language. Presentations could be made in English, French or German, although no translation facilities were provided. To assist in the understanding of papers and presentation, regulations governing the use of slides were drawn up by a subcommittee under the chairmanship of Professor Dr. E. F. Pfeiffer.

The heavy duty of translation of the abstracts was undertaken from Geneva by Professor Renold and his colleagues, as was the necessary re-typing, but as the number of abstracts increased so this task of translation became a time-consuming burden. Since 1974, abstracts have been published in English only, as a separate volume of abstracts, but paginated for inclusion in Diabetologia. This had the advantage of enabling the abstract to be quoted for reference, but the disadvantage of greatly increased costs. The English editing was carried out by Drs. R.J.Jarrett and P.H. Sönksen for many years, but has now been taken over by the Diabetologia editorial staff.

Generous subventions from Novo Industri covered the whole cost of production of the abstracts in the early

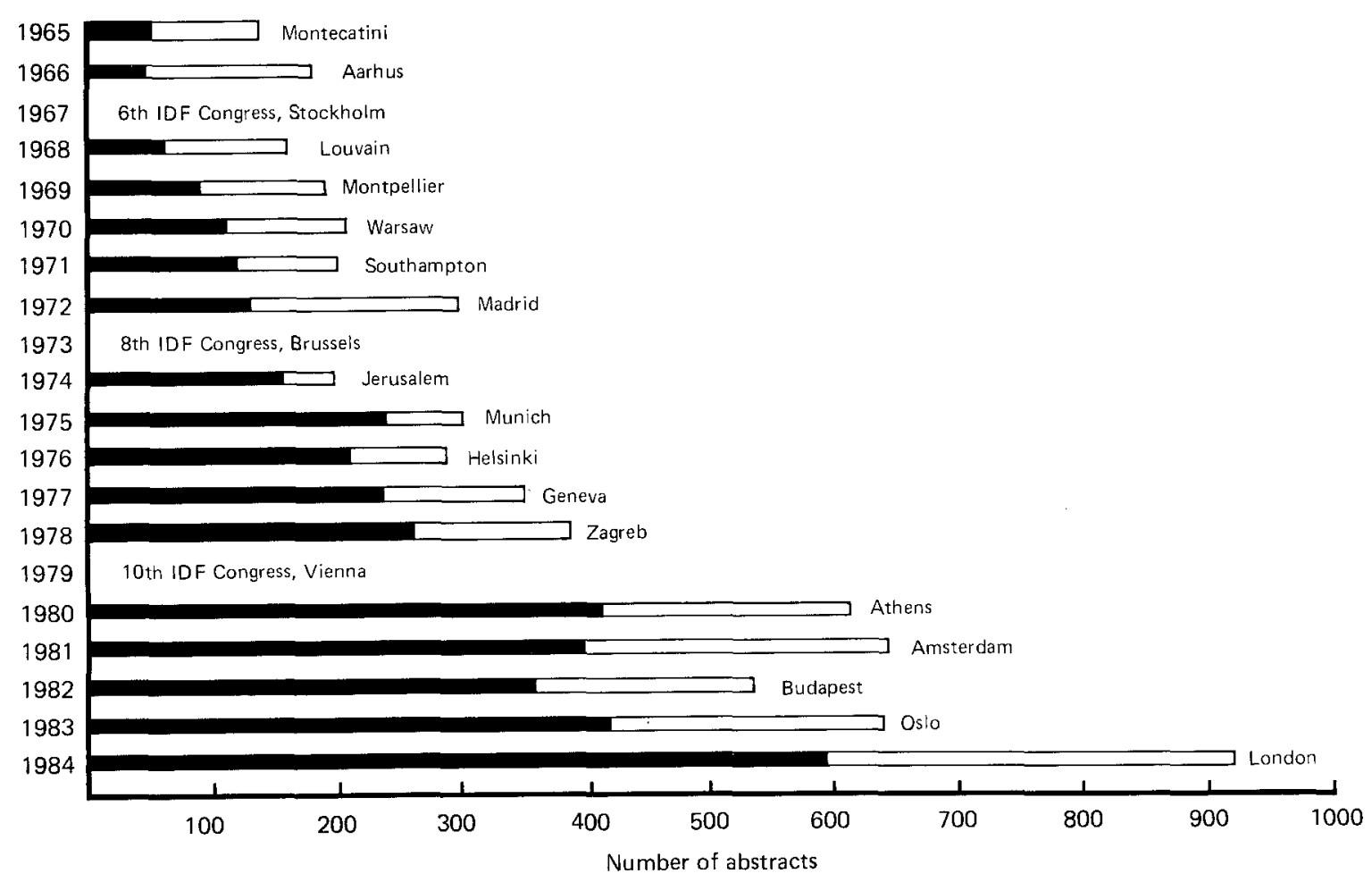

Fig.3. Number of abstracts submitted to EASD meetings: $\mathbf{\square} \square=$ Total number of papers submitted; $\mathbf{\square}=$ number of papers accepted 
years, but as the numbers increased so the value of the grant diminished to approximately $50 \%$ of the total cost. By 1981, the high cost of production forced the Council to agree to exclude abstracts which were not accepted for oral or poster presentation.

Ethical considerations led the Association to publish an Editorial in Diabetologia $(1978,15: 431)$ to give guidance to authors in respect of investigations in man. Over the years a few papers have been rejected for this reason. Similarly, abstracts which greatly exceed the maximum of 200 words are also rejected. In this connection, it is perhaps worth commenting that those authors who cheerfully sign the declaration that the abstract contains 200 words or less when this is obviously untrue are laying themselves open to reasonable doubt about their scientific calculations!

In 1984, for the first time, abstracts were considered in total anonymity. Anonymous selection was in fact first suggested in 1972, when it was rejected by the Council on the ground that such consideration could lead to a heavy bias in favour of those countries more conversant with English. However, an unwritten regulation now requires the Programme Committee to include whenever practical at least one abstract from each European country, and the 'code' was broken after selection to ensure this.

\section{Trade exhibition}

It has been traditional that a trade exhibition should be mounted at the same time as the Annual Meetings, and we are greatly indebted to the many companies which have loyally and effectively participated in this activity. Over the years, social trends have changed the direction of their support towards the provision of services and assistance to younger colleagues. Without their involvement, it would be difficult to arrange the Annual Meetings, which have achieved an enviable reputation both for the content of the meeting and the pleasantly informal atmosphere which brings together colleagues from all over the world.

\section{Registration fees}

For the first two meetings (Montecatini and Aarhus) no registration fee was charged. But since 1968, a charge has had to be made and this has constantly increased. Being anxious to preserve the youthful nature of the Association and its annual meetings, lower registration fees were introduced for those under the age of 35 in 1974; and adjusted to under the age of 40 in 1982.

The Council is very aware of the problems which high registration fees create, especially for younger members. The fees are set by the local Organizing Committee, and have to take into account the hiring of suitable premises and facilities, and the provision of services adapted to local custom. Every effort is made to keep these to a minimum, but the problem is com- pounded by the fact that the Association has not been in a position to offer any kind of guarantee to the local Organizing Committee against the loss which could be incurred. The financial risk is taken by the local committee, and may well devolve into a personal loss.

An additional difficulty relates to the estimation of the likely attendance at any meeting. Economic recession and cut-backs in departmental grants have not made as much difference as anticipated.

\section{Travel grants}

Since 1969, the Association has been fortunate to receive annual subventions from Novo Industri which has enabled us to give modest travel grants to young colleagues under the age of 35 years. In recent years, Pfizer-Europe has most generously provided additional monies for the same purpose, and further allocations have been made from the Association's own Travel Fund. More than 500 young colleagues have received grants totalling in excess of $£ 60000$, many of them for several consecutive years. The grants are now limited to first authors of papers accepted for oral or poster presentation, all of whom must be paid-up members of EASD. In addition, the number of grants is limited to not more than three to any one department.

\section{International cooperation}

The most noticeable aspect of European diabetes research, which is shown by retrospective investigation, is the way in which opportunities have been seized for inter-European, and indeed intercontinental, collaboration. Whereas in its infancy the number of abstracts emanating from more than one centre could be counted on the fingers of one hand, the opposite is now more common. Indeed, it sometimes seems as if more work must be done in the air than on the ground; or at any rate at some convenient airport, such is the multiplicity of authors from different centres and countries.

In part, this interchange of personnel was made possible by the valuable Travel Fellowships, amounting to $\$ 48000$ over 6 years, made available to the Association by Pfizer-Europe, and which enabled 16 Fellowships to be awarded for long-term stays in different centres. Unfortunately, such grants are no longer available.

\section{Attendance at Annual Meeting}

Attendance at the Annual Meetings is certainly linked with the venues, and in recent years has risen unpredictably, partly due to the introduction in 1977 of the rule that only one abstract may be submitted by any one author, who does not have to be a member of the Association, but who generally joins rapidly if his paper is accepted in order to gain the $50 \%$ reduction on the registration fee! 
Of the 3985 abstracts which have been accepted for presentation at the 17 Annual Meetings, $12 \%$ have been given by 59 authors (Table 8). The remaining 3513 papers have been given by 1929 authors, many of whom have been young colleagues presenting a paper for the first time. In fact, it is comparatively rare for any member over the age of 40 years to read a paper at our meetings, although they are very active in discussion. The standard of presentation has remained constantly high, especially when one remembers that for the majority English is not their mother tongue, and delivery is limited to $10 \mathrm{~min}$.

\section{Origin of papers}

Breaking down the meetings into three periods (1965-1972, 1974-1978, 1980-1984), the 16 leading con-

Table 8. Authorship of papers at Annual Meetings: 1965-1984

\begin{tabular}{|c|c|}
\hline $\begin{array}{l}\text { Eleven papers } \\
\text { presented by: }\end{array}$ & WJ Malaisse, WK Waldhäusl \\
\hline $\begin{array}{l}\text { Ten papers } \\
\text { presented by: }\end{array}$ & $\begin{array}{l}\text { L Boquist, RJ Jarrett, AS Luyckx, LOrci, H Schatz, } \\
\text { J Sehlin }\end{array}$ \\
\hline $\begin{array}{l}\text { Nine papers } \\
\text { presented by: }\end{array}$ & $\begin{array}{l}\text { A Anderssen, RAssan, EO Balasse, VGrill, } \\
\text { LG Heding, JC Henquin, JH Nielsen, P Schauder, } \\
\text { I-B Taljedal }\end{array}$ \\
\hline $\begin{array}{l}\text { Eight papers } \\
\text { presented by: }\end{array}$ & $\begin{array}{l}\text { SJH Ashcroft, L Barta, W Beischer, NJ Christensen, } \\
\text { IC Green, VA Koivisto, T Koschinsky, C Kuhl, } \\
\text { V Leclercq-Meyer, M Muggeo, H-H Parving, O Pe- } \\
\text { dersen, M Serrano-Rios, P Vague, J Zapf }\end{array}$ \\
\hline $\begin{array}{l}\text { Seven papers } \\
\text { presented by: }\end{array}$ & $\begin{array}{l}\text { HPT Ammon, OK Faber, JH Fuller, B Hellmann, } \\
\text { A Herchuelz, K Hermansen, TDR Hockaday, } \\
\text { PAH Holloway, B Karamanos, EM Kohner, R Ko- } \\
\text { rec, R Landgraf, Y Le Marchand-Brustel, A Louba- } \\
\text { tieres, CG Ostensen, DG Pipeleers, S Raptis, R Ren- } \\
\text { ner, EStandl, J Tamarit, JTamarit-Rodriguez, } \\
\text { A Tiengo, NS Track, ER Trimble, B Vialettes, } \\
\text { CB Wollheim, GHJ Wolters }\end{array}$ \\
\hline
\end{tabular}

Total number of papers presented: 3985 ; total number of presenting authors: 1988 tributors by country, based on the percentage of accepted abstracts, are given in Table 9.

Analysis of rejected papers over these periods produces similar league tables involving the same countries in virtually the same order; but when analysed on an annual basis, Italy is found to have suffered the highest rejection rate $(91 \%)$ in 1966 , closely followed by Sweden $(87 \%)$ in 1965.

Breaking down these facts into more specific centres where identification of the place of work is possible (London, for instance, is sub-divided into the various teaching hospitals, and Copenhagen excludes the diabetes centres at Gentofte and Klampenborg), Table 10 lists the 30 leading places of work of accepted abstracts given at the 17 Annual Meetings.

\section{Scientific content}

The first paper to be given in Montecatini was "The mechanism of the promotion by insulin of protein synthesis in muscle" by K. L. Manchester (UK). Since that time, insulin in all its complexities has remained in the forefront of discussions. Animal models vie with glucagon, GIP, immunology, pathology, lipids, kidney function, retinopathy, haemoglobin, somatostatin and new drugs for a place in the programme. The intricacies of the epidymal fat pad and rat diaphragm have given way to the alphabetical progression of tissue typing. The enigma of epidemiology remains unsolved. The archipelago of Langerhans continues to be a fruitful source of investigation. Sadly, the crippling complications still demand exhaustive study and explanation. The potentiality of growth hormone; the artificiality of micropumps for privileged people; dietary and nutritional advances; the pangs of pregnancy; the benefits of regular exercise; the personalization of home-monitoring and control; and the rather late re-discovery of the value of eduation, have all featured over the years.

Table 9. Annual meetings: accepted abstracts by countries: 1965-1984

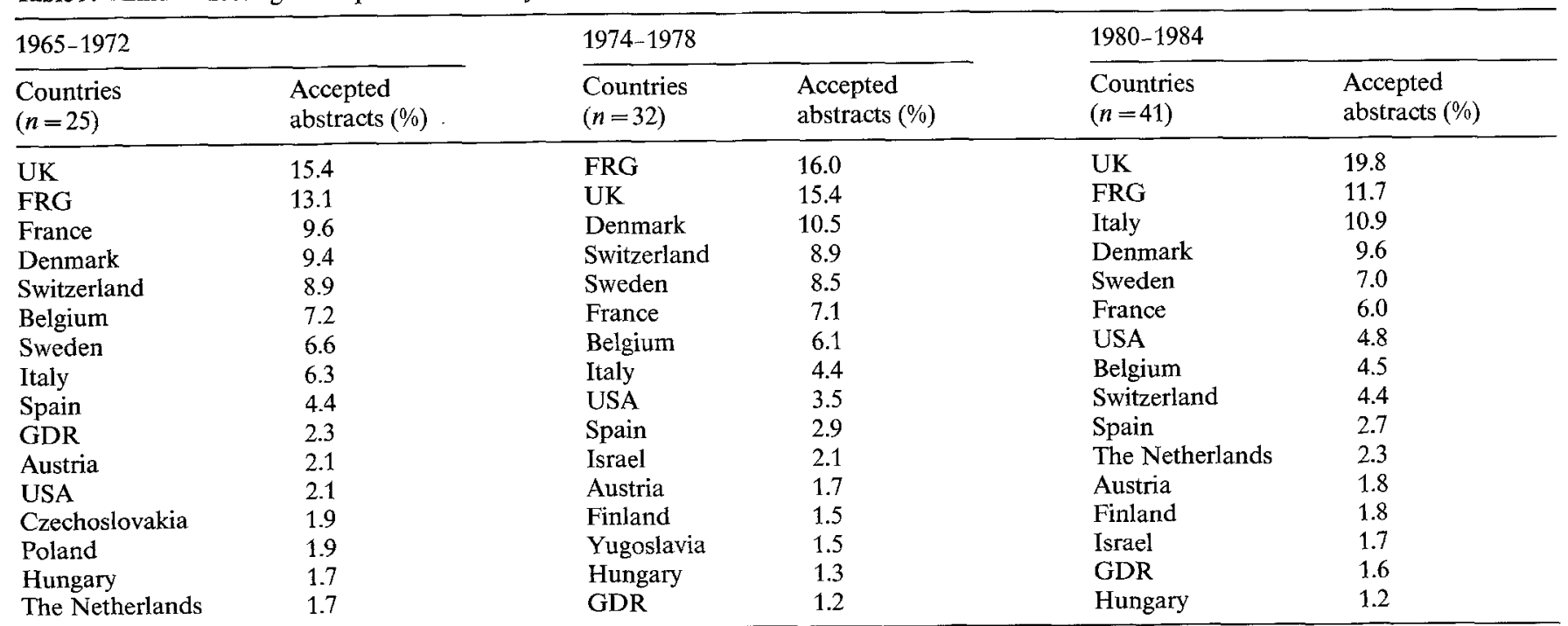


Table 10. Order of accepted papers by place of work

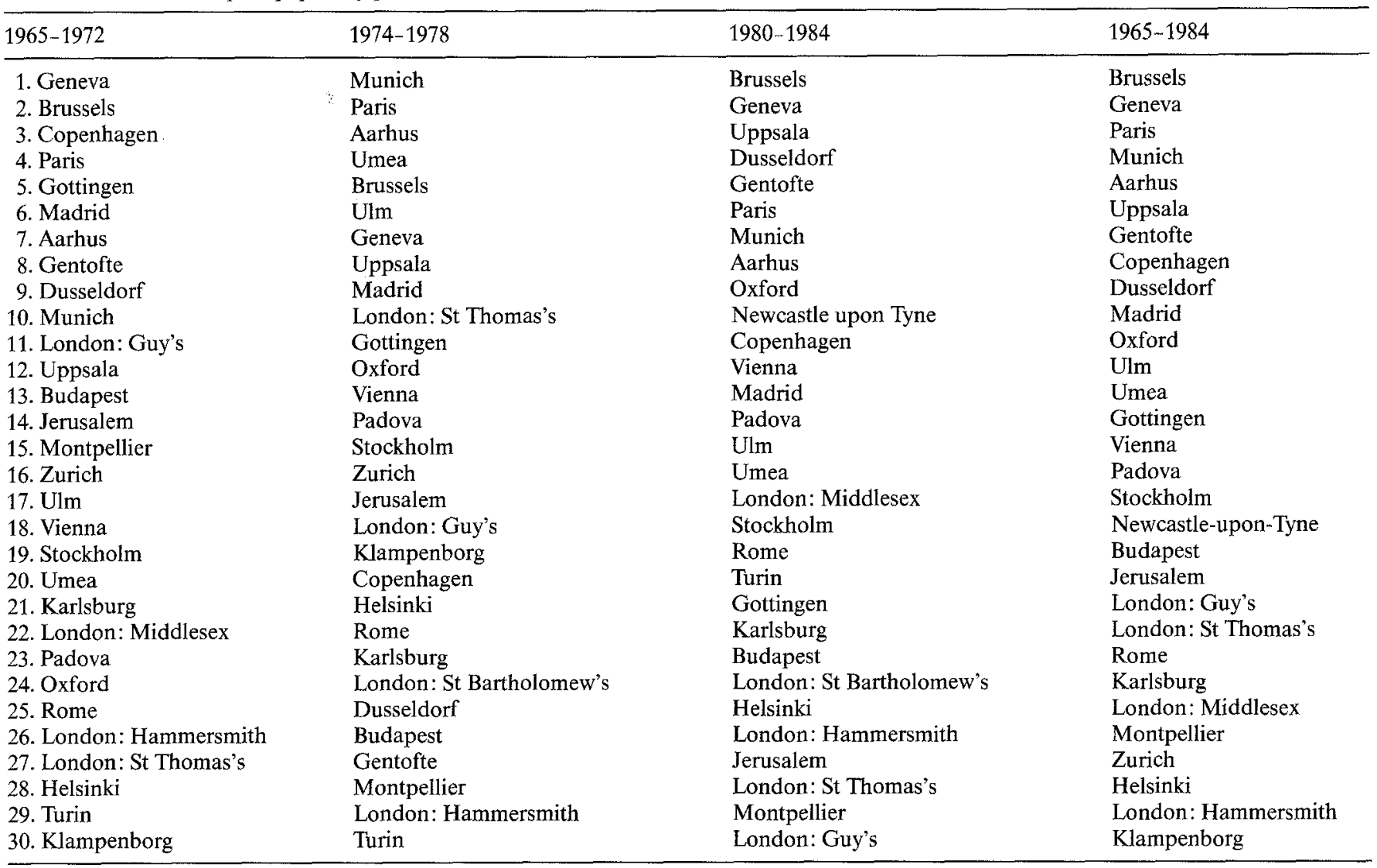

\section{Study groups and sub-committees}

Some of the topics discussed at the annual meetings are reflected in the creation of study groups, each of which is autonomous and self-suporting with its own constitution and rotation of officers, but closely linked and interwoven into the fabric of the Association. The first such group was the European Diabetes Epidemiology Study Group, founded in 1966 . This was closely followed by the Pregnancy Study Group, started in 1970. In 1979, the Diabetes Education Study Group (originally termed 'Patient Education') commenced its activities which have undoubtedly lead to an increase in the awareness of ways and means of improving both patient and professional education throughout Europe.

The Artificial Insulin Delivery Systems, including Pancreatic and Islet Transplantation Study Group (AIDSPIT) was formed in 1981: and since then two other groups have been started, namely Nutrition (1982) and Lipoproteins (1983).

Although technically any member of EASD is entitled to attend the study group meetings on payment of the appropriate meeting registration fee, in practice attendance is limited to those with specific interest and involvement in the subject under discussion, and frequently includes colleagues in other disciplines whose prime interest is not diabetes. Annual reports are given at the General Assemblies, and the activities of each group are monitored by the Executive Committee and the Council.

Conscious of its responsibility for improving standards of education and treatment throughout Europe, the Council appointed a Postgraduate Education Subcommittee in 1972 to progress earlier activity initiated by Drs. W.J.H. Butterfield, W.Creutzfeldt and J.J. Hoet. For 2 years written summaries of presentation at Annual Meetings were distributed, prepared by the Chairmen of sessions or appointed racconteurs, but this effort proved impossible to sustain.

In 1972, Dr. Z. Skrabalo and his colleagues organized the First EASD Postgraduate Course on Diabetes in Zadar, Yugoslavia; and its success lead to further courses being held in Yugoslavia, East Germany, Italy, Greece and Turkey. In addition, the sub-committee has cooperated with colleagues in other countries, notably Spain, Portugal and the United Kingdom, in the promotion of postgraduate education. International faculties are invariably involved, but in recent years there has been a welcome tendency to limit the number of invited speakers who interact with national colleagues.

\section{Finance}

Initially, the major financial support stemmed from the generous contributions of industry, which helped pay 
the proportion of costs relating to the launching of Diabetologia, which the Association agreed to meet for the first 5 years of publication.

A token subscription of SFr. 6 for Active Members was decided, but the expenses of collecting this far outweighed the value to our funds ( $<15 \%$ of total income). When the permanent secretariat was established in London, the subscription was increased to SFr. 20 , or $£ 2$, and since then has been raised at intervals to meet increasing administrative costs, especially in relation to Annual Meetings.

Since 1971, any surpluses resulting from Annual Meetings have been transferred to the Association and have been used to augment travel grants and other activities.

\section{General}

In such a review of activities over 20 years, it is impossible to cover in detail the many and varied topics which have been discussed by the Council. However, these included; the introduction of a single strength of U.100 insulin which was opposed (1972) with the comment that standardisation of syringes should take preference; an approach to the World Health Organization to urge the appointment of a permanent member of their staff to have responsibility for ensuring activity in the field of diabetes (1970); liaison with the IDF; negotiated preferential discounts on annual subscriptions to various international diabetes journals; diagnostic criteria; and the opening of bank accounts in East Germany and Hungary to facilitate payment of annual subscriptions by East European colleagues.

The aims of the Association, as laid down in the Constitution, are "to encourage and support research in the field of diabetes, the rapid diffusion of acquired knowledge and to facilitiate its application". With the exception of financial support for research, for which the Association has no funds, there is no doubt that these concepts have been fully developed over the first 20 years to create a thriving association.

J. G. L. Jackson 10 Queen Anne Street London W1N OBD UK 